\title{
Study of Evaluation of Electronic Infor- mation Student's Engineering Practice Ability Based on AHP
}

\author{
Dongyan Fan \\ Business College of Shanxi University,Taiyuan,China,fandongyan@126.com
}

\begin{abstract}
In this paper, the engineering practice ability evaluation index system which aims at the problem of electronic information students' engineering practice ability cultivation was designed. First the engineering practice ability indicators were collected using the method of the literature search and questionnaire survey, and then these primary indicators was repeated siftings using Delphi method. Second, using improved AHP to determine levels of indicators weights, while using questionnaire survey random sampling survey to related professional college students obtain the relevant data that needed for the evaluation though, and to implement applications of the evaluation index system. Finally, according to the evaluation model put forward corresponding countermeasures to improve the students' engineering practice ability.
\end{abstract}

Keywords: Engineering practice ability; Improved AHP; Delphi; Evaluation index system

\section{Introduction}

In the era of knowledge economy globalization, the electronic information engineering plays an important role in solving the complex problems associated with human life because of the rapid development of information technology, so the world pay especially attention to the engineering education reform. Train and bring up high-quality electronic information talents with engineering practice ability to participate in the construction and development of the enterprise is directly related to the success of building an innovative country. Practicality is the essential attribute of engineering properties, and also is the core issues of engineering education transformation from the traditional "scientific paradigm" to modern "engineering paradigm" .Research the Evaluation and application of electronic information specialty students practice ability has an important significance to promote the teaching reform of electronic information specialty, improve the quality of training engineering talents, create new electronic information Engineer, service innovation-oriented country.

\section{The establishment of evaluation in- dex system}

Electronic information specialty engineering talents training is based on strengthening practical ability cultivation of applied talents, and emphasizes the engineering quality training to satisfy the variety of enterprise requirements. The engineering and technical personnel should have the basic qualities.in the whole process of decision-making and the implementation of engineering practice .Establish a scientific evaluation index system engineering practice is the core of the engineering practical ability 
and it also is the key to realize the evaluation target.

Electronic information engineering students' engineering practice ability training throughout the higher education stage, it is a long and complicated process, it must follow the principle of comprehensive and systematic, it can't care for this and lose that. Considering the characteristics of the formation of the engineering practice ability, it is not only related to students themselves, also with the college teachers' teaching level, the school's management level, social environment and the social education are closely related. To evaluate students' engineering practical ability, must be analysis and grasp the above various factors comprehensive, find the mutual contact and mutual influence between them, improve the effects of these factors on students' engineering practical ability comprehensive and systematic. The way to training students' engineering practical ability can be finding only in this way.

The evaluation indexes were collected through the literature search and evaluation questionnaires by the author. These evaluation indexes have certain pertinence, authority and effectiveness, but it is more scattered and did not constitute a system. Therefore, the author also through expert interviews and access to relevant information, first identified four basic dimensions, and the above indexes were sorted to ensure the interrelated and logical relation between indexes. Thus the four basic dimensions of University dimension, Industrial dimension, Personal dimension, Social training institutions dimension were determined as the firstlevel indicators, while 25 indicators which frequency of appearing in the index statistics over 5 times as level 2 indicators of three level evaluation system, as shown in TABLE 1, the electronic information engineering practice ability evaluation index system was constructed ini- tially, and finally Delphi method was used to screening indexes.

TABLE 1 The primary indicators of engineering practice ability evaluation

\begin{tabular}{|c|c|}
\hline \begin{tabular}{|l|} 
Level1 \\
indicators
\end{tabular} & Level2 indicators \\
\hline \multirow{8}{*}{$\begin{array}{l}\text { University } \\
\text { dimension }\end{array}$} & The Professional curriculum setting \\
\hline & Practice course credit requirements \\
\hline & $\begin{array}{l}\text { Understanding of University to the needs of the } \\
\text { industry }\end{array}$ \\
\hline & The engineering practice experience of Faculty \\
\hline & $\begin{array}{l}\text { The evaluation standard of practice teaching quali- } \\
\text { ty }\end{array}$ \\
\hline & $\begin{array}{l}\text { The abundant degree of practice teaching re- } \\
\text { sources }\end{array}$ \\
\hline & School arranged the practice or internship tutor \\
\hline & Practice teaching system \\
\hline \multirow{5}{*}{$\begin{array}{l}\text { Personal } \\
\text { dimension }\end{array}$} & The individual practice consciousness \\
\hline & $\begin{array}{l}\text { The motivation to improve Personal Practical } \\
\text { Capabilities }\end{array}$ \\
\hline & Personal ability of knowledge transformation \\
\hline & $\begin{array}{l}\text { Intellectual curiosity and ability of lifelong learn- } \\
\text { ing }\end{array}$ \\
\hline & Communication and cooperation ability \\
\hline \multirow{7}{*}{$\begin{array}{l}\text { Industrial } \\
\text { dimension }\end{array}$} & Enterprises set up a specialized tutor for students \\
\hline & $\begin{array}{l}\text { Enterprises are willing to receive school students } \\
\text { to internships }\end{array}$ \\
\hline & $\begin{array}{l}\text { Enterprises are willing to recruit students without } \\
\text { work experience }\end{array}$ \\
\hline & Pre-service training of Enterprises for students \\
\hline & $\begin{array}{l}\text { Enterprises' continuing education of professional } \\
\text { fields to students }\end{array}$ \\
\hline & $\begin{array}{l}\text { Mutually beneficial relationships between enter- } \\
\text { prises and schools }\end{array}$ \\
\hline & $\begin{array}{l}\text { The exchange with Enterprise personnel in an } \\
\text { informal setting }\end{array}$ \\
\hline \multirow{5}{*}{$\begin{array}{l}\text { Social } \\
\text { training } \\
\text { institutions } \\
\text { dimension }\end{array}$} & $\begin{array}{l}\text { Training institutions staffs' ability of engineering } \\
\text { practice }\end{array}$ \\
\hline & $\begin{array}{l}\text { Involved in the professional and technical ap- } \\
\text { praisal of the industry }\end{array}$ \\
\hline & The pertinence of training content \\
\hline & Embodiment of training \\
\hline & Project resources of training institutions \\
\hline
\end{tabular}

Delphi method is widely used in all kinds of the establishment of evaluation index system and the process of determine specific indicators as a kind of subjective, qualitative method. The biggest characteristic of Delphi method is to make forecasts objectively and possibly. Eventually the electronic information specialty students engineering practice ability evaluation index system was built as shown in Fig. 1. In the evaluation index system, the indexes of 4 first-level 
indicators showing an interactive situation, which connected to each other, and restraining each other, interaction, there are institutions become standard engineering practice ability evaluation system, more fully reveals the electronic information engineering students' engineering practical ability of the connotation of the elements.

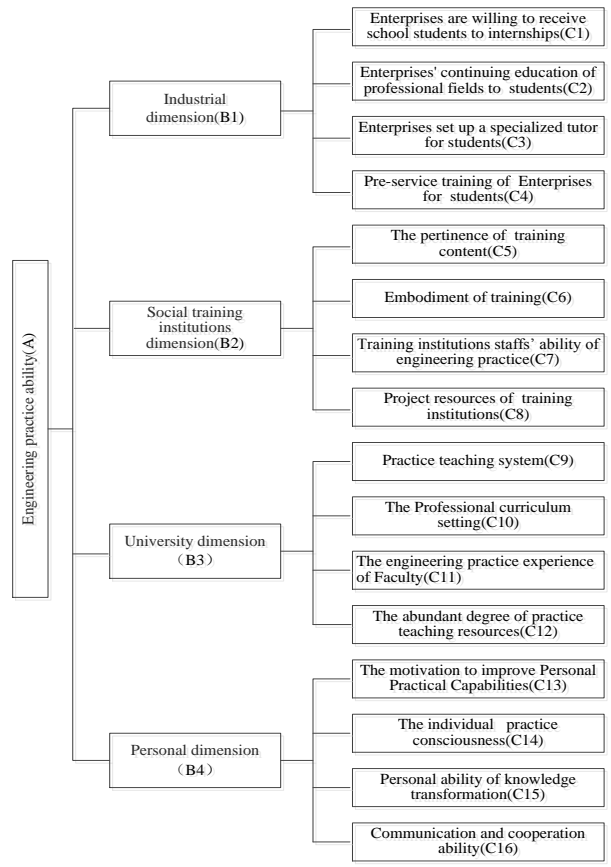

Fig. 1: Evaluation index system

\section{Analysis of the evaluation indexes based on AHP}

First, confirm that you have the correct template for your paper size. This template has been tailored for output on the US-letter paper size. If you are using A4sized paper, please close this template and download the file for A4 paper format called "CPS_A4_format".

The affiliations between each indicator were determined after the establishment of evaluation index system. The index system can really play the role of only when indicators at all levels were to given a certain weight. AHP was use in this pa- per. AHP was formally proposed by the U.S. Operations Research Experts T. L. Saaty in the mid-1970s. Its core idea is to put the evaluation of complex hierarchical. The evaluation questions was Constructed to multi-level structure including evaluation objectives, evaluation areas, evaluation index. The level single ranking (weights) and the total ranking calculated through qualitative indicators Quantization is as the systems approach which is applied in multi-index and Multi-plans optimization decision. AHP can decrease the difficulty of work and meanwhile it can improve the accuracy and science of the index weight; But it must be taken measures of verify the consistency to judgment matrix to determine the weighing values to improve the reliability and validity of the weights determine. So in this paper, the concept of optimal transfer matrix was Put forward to improve AHP, and let it meet the conformance requirements naturally, and thus the weight value can be calculated directly, and the tedious process of conformance testing can be revoked. The specific method is:

\subsection{To construct judgment matrix}

By the method of questionnaire investigation and expert scoring, the levell index, level 2 index of evaluation index system was pairwise comparison, judgment matrix table was obtained after the results was pooled analysis. As shown in Fig. 2:

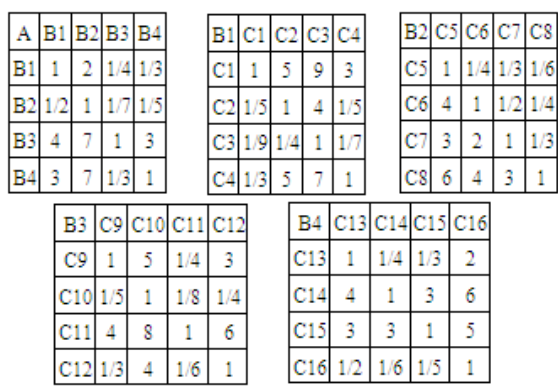

Fig. 2: Judgment matrix table 


\subsection{Seeking transfer matrix $B$}

The template is used to format your paper and style the text. All margins, column widths, line spaces, and text fonts are prescribed; please do not alter them. You may note peculiarities. For example, the head margin in this template measures proportionately more than is customary. This measurement and others are deliberate, using specifications that anticipate your paper as one part of the entire proceedings, and not as an independent document. Please do not revise any of the current designations.

Matrix B can be obtained according to the transfer matrix A:

$B=\log A=\left[\begin{array}{cccc}0 & 0.30103 & -0.60202 & -0.47712 \\ -0.30103 & 0 & -0.84510 & -0.69897 \\ 0.60202 & 0.84510 & 0 & 0.47712 \\ 0.47712 & 0.69897 & -0.47712 & 0\end{array}\right]$

3.3. Seeking optimal transfer matrix C

$$
\begin{gathered}
C_{i j}=\frac{1}{n} \sum_{k=1}^{n}\left(b_{i k}-b_{j k}\right) \\
C=\left[\begin{array}{cccc}
0 & 0.266737 & -0.675607 & -0.369280 \\
-0.266737 & 0 & -0.942344 & -0.636017 \\
0.675607 & 0.942344 & 0 & 0.306327 \\
0.369280 & 0.636017 & -0.306327 & 0
\end{array}\right]
\end{gathered}
$$

\subsection{Seeking quasi-optimal consistent matrix $A^{\prime}$}

$A^{\prime}=10^{C}\left[\begin{array}{cccc}1 & 1.848148 & 0.211053 & 0.427287 \\ 0.541082 & 1 & 0.114197 & 0.231197 \\ 4.738173 & 8.756778 & 1 & 2.024544 \\ 2.340347 & 40325308 & 0.493938 & 1\end{array}\right]$

\subsection{Seeking feature vectors $\lambda$}

$$
\begin{aligned}
& \lambda_{1}=\sqrt[4]{1 * 1.848148 * 0.211053 * 0.427287}=0.638943 \\
& \lambda_{2}=\sqrt[4]{0.541082 * 1 * 0.114197 * 0.231197}=0.345271 \\
& \lambda_{3}=\sqrt[4]{4.738173 * 8.756778 * 1 * 2.024544}=3.027400 \\
& \lambda_{4}=\sqrt[4]{2.340347 * 4.325308 * 0.493938 * 1}=1.495349
\end{aligned}
$$

\subsection{Normalized the vector $\lambda$ to seek power coefficient $X$}

$$
\begin{aligned}
& X=\left(\lambda_{1} / \sum \lambda^{\prime}{ }^{\lambda_{2}} / \sum \lambda^{\prime}{ }^{\lambda_{3}} / \sum \lambda^{\prime} / \lambda_{4} / \sum \lambda\right) \\
& =(0.1159,0.0630,0.5510,0.2721)
\end{aligned}
$$

$X_{1}, X_{2}, X_{3}, X_{4}$ can be calculated Using the same method, finally the weights of engineering practical ability evaluation index system can be obtained, as shown in TABLE 2.

TABLE 2 The weights of $\mathrm{n}$ index system

\begin{tabular}{|c|c|c|c|}
\hline $\begin{array}{c}\text { Level1 } \\
\text { indicators }\end{array}$ & Weights & $\begin{array}{c}\text { Level2 } \\
\text { indicators }\end{array}$ & Weights \\
\hline \multirow{3}{*}{$\mathrm{B} 1$} & \multirow{3}{*}{0.5501} & $\mathrm{C} 1$ & 0.5551 \\
\cline { 3 - 4 } & & $\mathrm{C} 2$ & 0.1030 \\
\hline & & $\mathrm{C} 3$ & 0.0409 \\
\hline & $\mathrm{C} 4$ & 0.3010 \\
\hline \multirow{4}{*}{$\mathrm{B} 2$} & \multirow{4}{*}{0.1159} & $\mathrm{C} 5$ & 0.5510 \\
\hline & & $\mathrm{C} 6$ & 0.0649 \\
\hline & & $\mathrm{C} 7$ & 0.2250 \\
\hline & & $\mathrm{C} 8$ & 0.1591 \\
\hline \multirow{4}{*}{$\mathrm{B} 3$} & \multirow{4}{*}{0.2721} & $\mathrm{C} 9$ & 0.3489 \\
\hline & & $\mathrm{C} 10$ & 0.5095 \\
\hline & & $\mathrm{C} 11$ & 0.0199 \\
\hline & & $\mathrm{C} 12$ & 0.1217 \\
\hline \multirow{4}{*}{$\mathrm{B} 4$} & \multirow{3}{*}{0.0630} & $\mathrm{C} 13$ & 0.0644 \\
\hline & & $\mathrm{C} 14$ & 0.5388 \\
\hline & & $\mathrm{C} 15$ & 0.2766 \\
\hline & & $\mathrm{C} 16$ & 0.1182 \\
\hline
\end{tabular}

By the quantitative analysis, engineering practice education can be understand fully though to scan the four key( universities, industry, students themselves, and social status of training institutions ) of engineering practice ability to forming. So that the development of electronic information engineering students engineering practice education can be planed scientific and rational, and make it's gradually took to the benign development path, the ability of engineering practice can be improved effectively.

\section{Application of the engineering prac- tical ability evaluation index system}

The index weight shows that the university has significant positive effect for the formation of students' practical ability. Construction of University practice teach- 
ing system, setting of professional courses, practice teaching resources and engineering practical experience of teaching staff are the important factors influencing the engineering practical ability. In the research we found that in recent years, the awareness of students' project practice ability training is improving, but the ascension of electronic and information profession graduates practical ability of most of the universities is not obvious. The capacity and quality of graduates with the requirements of the industry has a long distance. So we must reform the existing practice teaching system, and make the practice teaching link has gradation, continuity and penetration, a class of set According to subject logic must be broken, the course system of "basedcompetency" must be to establish, the relevant courses and practice teaching must be designed according to" "student outcomes".

Industry is also important to the cultivation of students' engineering practical ability. With the development of information technology, the market environment faced by industry is undergoing rapid change. In electronic information engineering under the present situation of the graduates practice ability is generally low; the problem through a series of policies and measures to safeguard and motivate the enterprise to participate in engineering practice education is an urgent need to consider. While enterprises should also have a sense of social responsibility, and gradually participate consciously the training of talent practice ability, and Assist universities bear some of the roles of higher engineering education, And through the co-operative education, receiving graduate internship, carry out to the student to develop continuing education training and other forms of practice and training.

Individual as the main subject and internalization of ability, and it's also played the role should not be overlooked in the process of ability to be formed and improved. Knowledge is a kind of learning ability which is produced in a certain environment and working background. Engineering practice ability as part of the individual ability, it also follows the basic theory of ability forming process. Therefore consciousness, power and the inherent ability of the individual are the important factors that affect its engineering practice ability strong or weak. But through survey statistics found that the electronic information engineering students' motivation to improve engineering practical ability is insufficient, so requiring all levels of the education sector through the reform of the current structure and course credit assessment mechanism, and through the proper guidance to enhance the motivation of students' initiative getting practical ability.

In the influence of the social training institutions, Studies have shown that, Due to the strengthening of specialization, social training will play an increasingly important role, many training function of universities and industrial will be gradually replaced by the social training institutions. The influence of the social training will be more and more important to enhance the practical ability. Social training will be an important channel for practice ability of engineering talents training.

\section{Conclusion}

Under the macroscopic background of the construction of an innovative country, we should clearly recognize that the development of the enterprise and product innovation in addition to rely on the fair market environment and a good system of intellectual property rights protection, it should also mainly rely on talent, especially the engineering technology talents with engineering practice ability. But the cultivation of engineering practice ability, 
is not entirely responsibility of universities, it will be affected by the social environment, so it requires sustained effort of government departments, universities, enterprises, teachers and students. Especially in the aspect of practice teaching reform, in addition to changing concepts and really realize the importance of the leading factors which has a decisive role in practice teaching, that must have the systematic implementation measures: we must to allow sufficient time For engineering practice of students ,and to provide sufficient space, proper teaching requirements, practical content, teaching methods and evaluation methods, and we also must give full play to the student's personality and initiative to stimulate student enthusiasm for engineering practice. In this paper, the key factors influencing the engineering practical ability has carried on the qualitative and quantitative analysis, and the operational countermeasures to the development of the engineering practice education and the improving of engineering practice ability cultivating was proposed. But the complexity of the relative to the object of study, this research still exist certain limitations, only to the region specialized electronic information carried on the analysis, that need to expand and improve in the future study.

\section{References}

[1] ACEE. The Attributes of Cooperative Education Programs [EB/OL]. http:// www.co-opaccreditation. org/attributes.htm, 2011-07-08.

[2] Boeing, Desired Attributes of an Engineering $[\mathrm{EB} / \mathrm{OL}]$.

http://www.boeing.com/educationrela tions/attributes.html, 2011-10.
[3] Rover, D. T. Attention Engineering Educators[J]. The Journal of Engineering Education.2008, 97(4): 351354.

[4] Hal Abelson. The Creation of Open Course Wareat MIT[J].Journal of Seienee EdueationandTeehnology,Vol.17,No.2,APril2008.

[5] Bi Zhongyi .The Research of Development of Innovative Engineering and Technical Talent [D].Lanzhou University.2012

[6] Mi Weizhe,Liu Sijia,Nie Zhiqiang. To analyse function of engineering practice teaching based on the training of outstanding engineers $[\mathrm{J}]$. Experimental Technology and Management. 2013, (10)

[7] Zhang Jie,Duan Zaichao,Wei Shiliang,Zhou Guiying. Exploration of Communication Engineering Practical Teaching based on Engineering Project Model[J]. China Educational Technique \& Equipment. 2013, (12)

[8] REN Zheng-yi,LIU Si-jia,WANG Dong. Engineering Consciousness of Modern Engineers [J]. Research and Exploration in Laboratory. 2013, 32(3)

[9] YU Cai-li. Strengthening Practical Teaching and Promoting the Cultivation of Outstanding Mechanical Engineers[J].Journal of Zhejiang Institute of Science and Technology.2012, 29(z1)

[10] Wang Zhongyong. On the Application of Practice Teaching in the Teaching of Engineering Subjects[J]. Journal of Jixi University. 2013, (10)

[11] HEN Ming-xin,LI Ying-sen,XU Shao-chuan,LI Qi. Exploration and practice of engineering-case teaching method in metallurgical industry automation[J]. Journal of University of Science and Technology Liaoning. 2012, 35(2) 